Available online at: https://proceeding.researchsynergypress.com/index.php/cpmhs/index

RSF Conference Series: Medical and Health Science

e-ISSN (to be processed) / p-ISSN (to be processed)

Volume 1 Number 1 (2021): 9-13

\title{
Effect of Unbalanced Nourishment on Growth Period to Memory in Mice
}

\author{
Arief Budi Yulianti ${ }^{1}$, Widayanti², Ike Rahmawaty ${ }^{2}$ \\ ${ }^{1}$ Medical Biology, Faculty of Medicine, Universitas Islam Bandung, Indonesia \\ ${ }^{2}$ Phisiology, Faculty of Medicine, Universitas Islam Bandung, Indonesia
}

\begin{abstract}
Quality of life in adulthood is determined by the quality of life of the embryo. Nutrition determines the quality of embryo life. The purpose of this study was to analyze the effects of unbalance nourishment on memory in the mouse. This research is an experimental study using mice as experimental animals. Twenty-four mice were divided into four groups. Group 1 was given standard nourish (Feed 1), Group 2 was given high carbohydrate (Feed 2), Group 3 was given high protein (Feed 3), Group 4 was given a high fat (Feed 4) from weaning to pregnancy. Parameters measured were a memory with new objects recognition (NOR) methods. The result was mice with unbalance nourishment had memory decrease between after and before treatment. This can be explained by the calorie content of each feed. Feed 2 contains the smallest calories $(2.89 \mathrm{Kcal})$. This means that the nutritional components are not sufficient as well as the calorie needs. Further research is unbalanced nourishment in the first generation will be passed on to the next generation.
\end{abstract}

Keywords: growth period; memory; mice; nourishment; unbalance

This is an open access article under the CC-BY-NC license

\section{INTRODUCTION}

Nourishment intake during the growth period is very necessary. Complete nourishment consists of carbohydrates, proteins, fats, vitamins, minerals, and water. Nutritional needs depend on age, gender, daily activities, and nutritional status (Feeney et al., 2017; Wahlqvist, 2020).

In Indonesia, people's habits are eating with high carbohydrates and have the term 'you haven't eaten if you haven't met rice'. In the development period, especially at under five years old, they need more protein calories. This will result in growth barriers such as stunted in children under 13 years old (Titaley et al., 2019).

Stunting due to chronic under nutritional intake from pregnancy until two years old. The stunting incidence in Indonesia reaches $27.5 \%$, or it can be said that one in three Indonesian children get stunting (Kurniawan, Rudy; Kurniasih, 2018). This impacts the immune system, intelligence, and children's activities. If this condition is not handled, it will be affected the survival of the Indonesian country. Stunting can be prevented by adequate nutritional intake since the child is in the womb, after birth, and get exclusive breastfeeding, and complimentary food with balanced nutrition, and be in a clean environment (Brahm and Valdés, 2017).

This research is part of our research is dealing with stunting, and in this paper, we are concern about the effects of unbalanced nourishment intake during the growth period until adulthood. This research used mice just been weaned as experimental animals exposed to unbalanced nourishment intake until the 
mice became pregnant and gave birth. The parameter was the memory of mice in the introduction of new objects.

\section{LITERATURE REVIEW}

Nutrition is closely related to all life activities at the cellular, tissue, organ, and individual levels. Nourishment is needed, such as carbohydrates, proteins, fats, minerals, and water. And nutritional needs depend on age, gender, activity, and health status. Nutrition can be divided into macronutrients consisting of carbohydrates, proteins, and fats, micronutrients consisting of vitamins and minerals, and water (Feeney et al., 2017; Wahlqvist, 2020).

Carbohydrates can be divided into simple carbohydrates such as monosaccharides, complex carbohydrates such as starch, and fiber. Simple sugars, especially glucose, are the main source of energy the body needs so that glucose levels in the blood are always maintained. Protein plays a role in metabolism and the body's building structure. Fat plays a role in steroid metabolism and heat insulation so that the body can adjust to an environmental temperature (Wahlqvist, 2020).

Good nourishment is nourished with a balanced composition of macronutrients and calories needed depend on daily activities. The average calorie requirement for adults is 2000 for moderate activity. Carbohydrates and fat per gram produce $4 \mathrm{Kcal}$ of energy, while fat is $9 \mathrm{Kcal}$. The question is, if the energy needs are fulfilled but only come from one macronutrient such as only carbohydrate, protein, or lipid, what happens to the body's metabolism, will it affect the growth and level of intelligence. This is the research question in this study, using mice as experimental animals exposed to unbalanced nutrition even though the energy is quite adequate by measuring memory as a major component of intelligence level (Çoban, Alver and Aslan, 2011).

\section{RESEARCH METHOD}

This research was an experimental study using a female mouse from Biofarma. The maintenance, treatment, and sacrification in this study are under ethical procedures for experimental animals. Twentyfour mice, 3 - 4 weeks old, were divided into four groups. Group 1 to Group 4 were given standard nourish (Feed 1), high carbohydrate (Feed 2), high protein (Feed 3), and high fat (Feed 4), respectively. The mouse was fed from 5 weeks old, pregnancy, childbirth, breastfeeding until wean off. Composition feeds one to four can be seen in Table 1. The Feeds were done at the Animal Maintenance Laboratory, School of Pharmacy ITB. The parameters measured are weight and memory with New objects recognition (NOR) methods before and after treatment.

New object recognition (NOR) was measured at the research center Faculty of Medicine, Universitas Islam Bandung. The initial step was to observe mouse behavior for as long as two minutes in a cube with size $50 \times 50 \times 50 \mathrm{~cm}$ completed by webcam. The next step was to lay two objects at a distance of $30 \mathrm{~cm}$ from each other, and mouse behavior was observed for as long as two minutes. The last step was replaced by one object with a new one, and mouse behavior was observed for as long as two minutes. The time length to recognize a new object is noted (Leger et al., 2013).

Table 1. Composition of mouse feed.

\begin{tabular}{lccccc}
\hline \hline & Raw Material & Feed 1 & Feed 2 & Feed 3 & Feed 4 \\
\hline \hline 1 & CP 551 & + & + & + & +
\end{tabular}


2 Rice flour

3 Cassava flour

$4 \quad$ Fish flour

5 Duct albumine

6 Duct yolk

$7 \quad$ Soluble cow fat

\section{$+$}

$+$

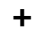

$+$

$+$

\section{FINDINGS AND DISCUSSION}

\section{Mice Feed}

Analysis mouse feed examination results (Table 2). Feed 1-4 calorie contain per $100 \mathrm{~g}$ were 77.6; $42.49 ; 148.76 ; 47.28 \mathrm{Kcal}$ respectively. The average consumption of feed 1- 4 per day per mouse was 6.5; $6.8 ; 7.1$; and 6.2 g or equivalent to $5.04 ; 2.89 ; 10.56 ; 2.93 \mathrm{Kcal}$, respectively.

According to NCBI, Nutrient Requirements of the Mouse, the average consumption of mouse feed was $3.5 \mathrm{~g} /$ day or $3.9 \mathrm{Kcal} /$ day (NCBI, 1995). In this study mice group fed with feed1 (CP551), average consumption was $6.5 \mathrm{~g} / 5.04 \mathrm{Kcal}$, feed2 (high carbohydrate) average consumption was $6.8 \mathrm{~g} / 2.89 \mathrm{Kcal}$, feed3 (high protein) average consumed was $7.1 \mathrm{~g} / 10.56 \mathrm{Kcal}$, and feed4 (high fat) average consumed of $6.2 \mathrm{~g} / 2.93 \mathrm{Kcal}$. This condition can be said that the amount of feed consumption is higher in this study, but the energy value is smaller, especially for feeds 2 and 3.

Table 2. Analysis of the nutritional content of mouse feed

\begin{tabular}{clccccc}
\hline \hline No & Sample & \multicolumn{5}{c}{ Composition (\%) } \\
& & Water & Dust & Lipid & Protein & Carbohydrate \\
\hline \hline 1 & Feed 1 & 6,0 & 5,8 & 0,04 & 3,1 & 19,3 \\
2 & Feed 2 & 6,5 & 5,4 & 0,01 & 1,2 & 9,4 \\
3 & Feed 3 & 6,1 & 10,6 & 0,04 & 5,1 & 32,0 \\
4 & Feed 4 & 7,1 & 3,1 & 0,41 & 1,5 & 9,4 \\
\hline \hline
\end{tabular}

Note: KK Kimia Analitik, Departemen Kimia, MIPA ITB

Ingredient in $100 \mathrm{~g}$

\section{Memorie Measurement}

The median time required for recognition of new objects in Feed1 before and after treatment was 98.71 and 82.29 seconds, in Feed2 was 120 and 105.14 seconds, in Feed3 was 97 and 92.88 seconds (Figure1). This means the time needed to recognize a new object decrease. But in Feed4, the median time needed to recognize new objects before and after was 78.88 and 93.13 seconds. This means the time needed to recognize new object increase. In this study, the time needed to recognize new objects before and after treatment for all groups of mice was different, although not statistically significant $(p=0.648)$. 
RSF Conference Series: Medical and Health Science, Vol. 1 (1), 9-13

Effect of Unbalanced Nourishment on Growth Period to Memory in Mice Arief Budi Yulianti, Widayanti, Ike Rahmawaty

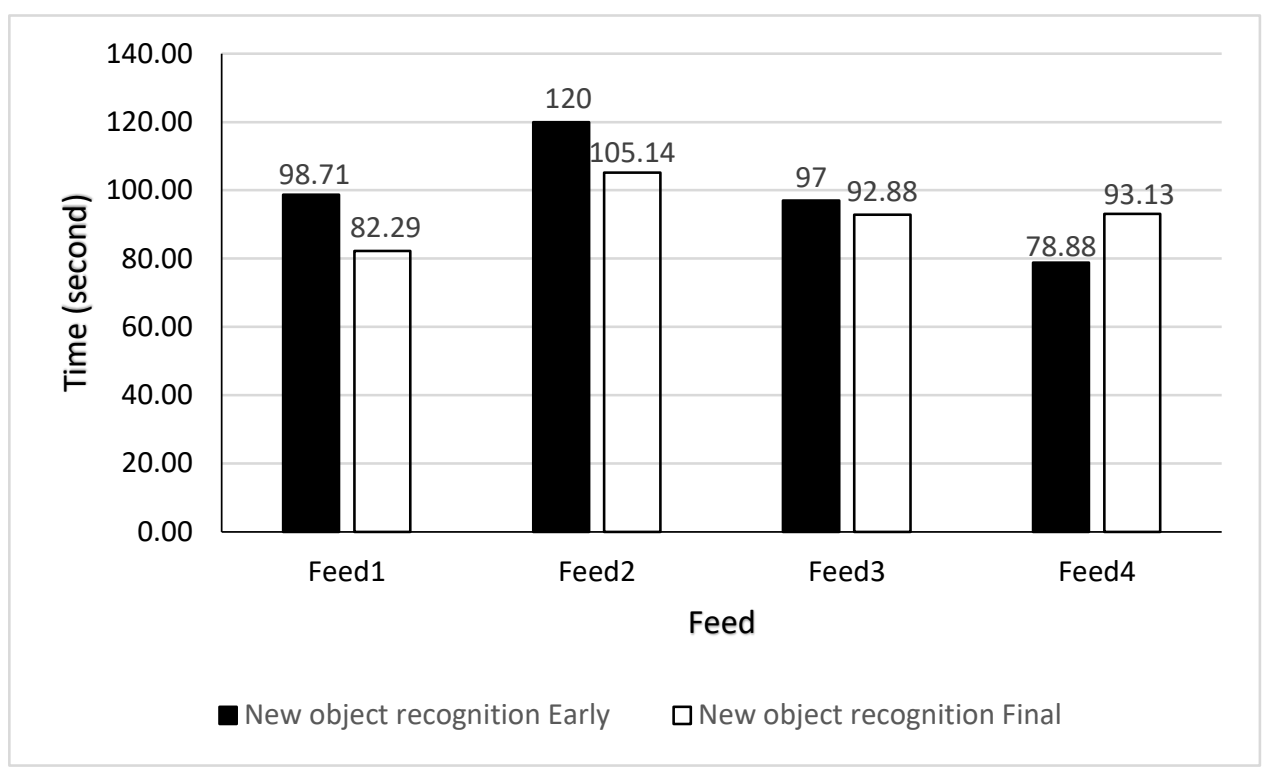

Figure 1. New Object Recognition (NOR)

Notes:

Feed1 was mice group were fed Standart nourish (CP551)

Feed 2 was mice group were fed high carbohydrate nourish

Feed 3 was mice group were fed high protein nourish

Feed 4 was mice group were fed high lipid nourish

\section{Discussion}

The body needs nourishment, especially during the growth period. Generally, the growth parameters are weight and height. Basically, when growth is disturbed, systematically disrupt all beginning from the cells, tissue, and organs, including the volume of the brain. Brain volume decreased the effect on intelligence caused memory to reduce (Calder et al., 2020)

In this study, the time required to recognize new objects was faster than before treatment, meaning that the mice fed the high-carbohydrate and protein diet were the same as the mice fed the standard diet but different from the mice fed the high-fat diet. This can be explained by the calorie content of each feed. Feed 2 contains the smallest calories $(2.89 \mathrm{Kcal})$. This means that the nutritional components are not sufficient as well as the calorie needs (Feeney et al., 2017)

Measurement of intelligence level with intelligence quotient (IQ). Many factors are measured by determining IQ and one of them is memory. Measurement of memory in humans is one of them by remembering a sequence of numbers from large to small and vice versa or by remembering groups of two, three, or four number sequences. In mice, memory is measured by the introduction of new objects, how long the mice can recognize new objects. In general, mice will immediately recognize a new object, and if disturbed by their memory, mice will not recognize a new object. The results of this study there is a difference in the time to recognize new objects in mice before and after treatment (Ginsburg and Gevers, 2015, Giofrè, Mammarella, and Cornoldi, 2014)

The limitation of this study is that feeds cannot be completely separate as carbohydrates, protein, or fat only. The results of the laboratory examination were feed composition mix together among carbohydrate, protein, and fat. The differences among feed1- 4 were in the calorie content only. 


\section{CONCLUSION AND FURTHER RESEARCH}

Incomplete feeding affects memory decrease in mice. The mice exposed to low-calorie diets shown memory decrease, although the differences were not statistically significant.

This research will be continued with research in the second and third generations with the aim to prove whether unbalanced nourishment in the first generation will be passed on to the next generation.

\section{REFERENCES}

Brahm, P. and Valdés, V. (2017) "Sociedad Chilena de Pediatría ClInICal OveRvlew Benefits of breastfeeding and risks associated with not breastfeeding Beneficios de la lactancia materna y riesgos de no amamantar," Rev Chil Pediatr, 88(1), pp. 15-21.

Calder, P. C. et al. (2020) "Reply to 'comment on: Optimal nutritional status for a well-functioning immune system is an important factor to protect against viral infections. nutrients 2020, 12, 1181,"' Nutrients, 12(8), pp. 1-3. DOI: 10.3390/nu12082326.

Çoban, E., Alver, B. and Aslan, A. (2011) "The Effect of Certain Types of Nourishment on the Intelligence Performance of 7th Class Students of Primary School Students.," International Online Journal of Educational Sciences, 3(2), pp. 494-509. Available at: https://acces.bibl.ulaval.ca/login?url=https://search.ebscohost.com/login.aspx?direct=true\&db=eue\&A $\mathrm{N}=65156835$ \&lang=fr\&site=ehost-live.

Feeney, E. L. et al. (2017) "Patterns of dairy food intake, body composition and markers of metabolic health in Ireland: results from the National Adult Nutrition Survey," Nutrition \& Diabetes. Nature Publishing Group, 7(2), pp. e243-e243. DOI: 10.1038/nutd.2016.54.

Ginsburg, V. and Gevers, W. (2015) "Spatial coding of ordinal information in short-and long-term memory," Frontiers in Human Neuroscience, 9(JAN), pp. 1-10. DOI: 10.3389/fnhum.2015.00008.

Giofrè, D., Mammarella, I. C. and Cornoldi, C. (2014) "The relationship among geometry, working memory, and intelligence in children," Journal of Experimental Child Psychology, 123(1), pp. 112-128. DOI: 10.1016/j.jecp.2014.01.002.

Kurniawan, Rudy; Kurniasih, N. (2018) Stunting, Kementrian Kesehatan Indonesia.

Leger, M. et al. (2013) “Object recognition test in mice," Nature Protocols, 8(12), pp. 2531-2537. DOI: $10.1038 /$ nprot.2013.155.

Titaley, C. R. etal. (2019) "Determinants of the stunting of children under two years old in Indonesia: A multilevel analysis of the 2013 Indonesia basic health survey," Nutrients, 11(5). DOI: 10.3390/nu11051106.

Wahlqvist, M. L. (2020) Introduction to human nutrition, Food \& Nutrition. DOI: 10.4324/9781003115663-2. 